\title{
Mineral nitrogen content in hydrographic areas of Poland depending on land use $*$ *
}

\author{
Anna Watros ${ }^{1}$, Halina Lipińska ${ }^{2}$, Wojciech Lipiński ${ }^{3}$, Przemysław Tkaczyk ${ }^{4} \mathbb{D}^{-}$, Jaromir Krzyszczak $^{5 * \mathbb{D}}$, \\ and Piotr Baranowski ${ }^{5}$ \\ ${ }^{1}$ New Chemical Synthesis Institute, Al. Tysiąclecia Państwa Polskiego 13 A, 24-110 Puławy, Poland \\ ${ }^{2}$ Department of Grassland Science and Landscaping, University of Life Sciences in Lublin, Akademicka 15, 20-950 Lublin, Poland \\ ${ }^{3}$ State School of Higher Education in Chełm, Pocztowa 54, 22-100 Chełm, Poland \\ ${ }^{4}$ Department of Agricultural and Environmental Chemistry, University of Life Sciences in Lublin, Akademicka 15, \\ 20-033 Lublin, Poland \\ ${ }^{5}$ Institute of Agrophysics Polish Academy of Sciences, Doświadczalna 4, 20-290 Lublin, Poland
}

Received October 29, 2018; accepted May 7, 2019

\begin{abstract}
One unintended consequence of nitrogen use in agriculture is an increase in nitrate content in ground waters. Nitrogen content was evaluated in soil samples from specific hydrographic regions of Poland from the $60-90 \mathrm{~cm}$ soil layer, in which this nutrient is not readily available to the main root mass of crop plants and may negatively affect the environment. It was revealed that $\mathrm{N}_{\min }$ content in specific hydrographic regions was highly dependent on both the soil type and land use. Notably higher values of $\mathrm{N}_{\min }$ content were observed for organic soils. The highest $\mathrm{N}$ contents were found in the grasslands of the northwestern area of Poland, while they were slightly lower in several regions of the main Odra River catchment and west of the Vistula River. The area with a high $\mathrm{N}_{\min }$ content in soils under maize was significantly larger compared to the grasslands area and primarily included the hydrographic regions of the Odra River basin in its south-western stretch, and of the Vistula River on its western and south-eastern side. With regard to the arable land under mixed cereals, the soils with the highest $\mathrm{N}_{\min }$ content in the non-root layer were predominantly located in hydrographic regions belonging to the main Odra catchment and to the catchment of the Vistula River in its upper course.

Keyw ords: nitrogen, spatial distribution, hydrographic areas, land use, grassland
\end{abstract}

*Corresponding author e-mail: jkrzyszczak@ipan.lublin.pl

**This work has been partly financed from the funds of the Polish National Centre for Research and Development in frame of the project BIO-FERTIL, contract number: BIOSTRATEG3/347464/5/ NCBR/2017 (2018-2021).

\section{INTRODUCTION}

Nitrogen is the most yield-increasing nutrient of plants and the importance of its role in agricultural production is beyond question. Nevertheless, there are non-production consequences of nitrogen use in agriculture, among which the increase in nitrate content in crop plants as well as in ground and surface waters is the most important one. Mineral nitrogen leached from the topsoil layers to the $60-90 \mathrm{~cm}$ layer of the soil profile is considered to be unavailable for the main root mass of crop plants. Therefore, research into nitrogen migration to deeper layers of the soil profile is extremely important, both in terms of nitrogen loss estimation and potential groundwater pollution. Research is also being carried out concerning the possibility of phytoremediation of nitrates from the soil, for example Marecik et al. (2013) showed high nitrogen removal rates for the treatment of industrial wastewater with a high concentration of $\mathrm{N}-\mathrm{NO}_{3}$ using sweet flag (Acorus calamus), common reed (Phragmites communis) and broadleaf cattail (Typha latifolia). It should be noted that much attention is now being paid to nitrogen losses and the resultant problems of water pollution in the context of the document known as the Nitrate Directive and the Helsinki Convention (Directive, 91/676/ CEE; Convention, 1992; Directive, 2000/60/EC). The main

(C) 2019 Institute of Agrophysics, Polish Academy of Sciences 
assumptions of the Nitrate Directive are focused on preventing the causes of eutrophication as a serious threat to water quality (Directive, 91/676/CEE; Randal and Goss, 2008). Hence, the quantities of soil mineral nitrogen, which have been recorded for years, are an important indicator of the effects of nitrogen on water quality (Regulation, 2002; Fotyma et al., 2010; Lipiński, 2010).

Apart from the environmental aspect, monitoring nutrient changes in various soil layers over the years and making an attempt to correlate these changes with the influence of various factors is significant both from a scientific and practical point of view. Such information is the basis for constructing simple empirical models based on, for example, multiple regression equations, that allow for the prediction of nutrient content in the studied soil and thus help farmers to plan the rational use of fertilizers in order to ensure an optimal nutrient supply for crop growth and to increase soil productivity using only a limited set of soil properties (Tkaczyk et al., 2017; 2018a; 2018b). Knowledge concerning nutrient content, especially NPK balance, and their relationship with other soil physicochemical properties are important for agrophysical modelling (Walczak et al., 1997; Lamorski et al., 2013). All of these models need input data to run, therefore representative data, especially at a large scale, are sought by modellers using and developing crop growth and yield models. Detailed information put into agrophysical models may constitute a new quality in research on how crop production will change in the conditions of a changing climate (Pirttioja et al., 2015; Fronzek et al., 2018) and how different cultivation and fertilization methods will impact this production (Ruiz-Ramos et al., 2018; Rodríguez et al., 2018). The balance of NPK also depends on the root system of the plant species and the level of mineral and organic fertilization (Antonkiewicz et al., 2018; Watros et al., 2018). The content of mineral nitrogen in the soil is also impacted by the biological activity of the soil, which in turn may be influenced by soil moisture (Wnuk et al., 2017) or $\mathrm{N}$ fertilization (Walkiewicz et al., 2018), and by atmospheric conditions. For this reason, research concerning the spatio-temporal variability of meteorological series from different climate zones (Baranowski et al., 2015; Hoffmann et al., 2017; Krzyszczak et al., 2017a; 2017b; 2019) and their prediction (Murat et al., 2018) is extremely important. It allows for the assessment of the likely impact of climate change not only on agricultural production, but also on the content of macroelements (NPK) in the soil.

About $1 / 5$ of the total area of soil used for agriculture is occupied by grasslands (GUS, 2018). The location, area and shape of these grasslands are physiographically determined, which prevents arbitrary changes. This results in high grassland area stability (Wasilewski, 2010), also the location of grasslands among crop fields, water bodies and watercourses as well as the large variations in habitat conditions indicate their exceptional role in the natural environment (Wasilewski, 2009). Despite a decrease in the area of both arable land and grasslands in the 21 st century, the yields of plants obtained per surface unit are increasing, which is related to the intensity of plant production, and thus with the more pronounced impact of agricultural land on the natural environment. Therefore, it is necessary to search for solutions optimizing the management of macroand microelements, including nitrogen, that will take into account the diversity of Polish soils and land use.

The results of previous research mainly concerned the scale of nitrogen outflow, as well as the impact of various factors on the migration of this nutrient into the soil profile, mainly on arable land. Grasslands, including those located on organic soils, have not been the subject of wider analyses. Thus far, the amount of mineral nitrogen in the soil layer $60-90 \mathrm{~cm}$ from grassland soils with regard to agricultural fodder crops has not been examined. Also, the potential impact of this form of nitrogen on water quality in the hydrographic regions of Poland has not been studied previously.

Therefore, taking into account the environmental effects, as well as production and economic considerations, this study attempted to evaluate the mineral nitrogen content in the $60-90 \mathrm{~cm}$ soil layer in grassland soils with regard to selected agricultural fodder crops in Poland's hydrographic regions.

\section{MATERIALS AND METHODS}

The evaluation of the soil mineral nitrogen content was performed based on the results of environmental investigations conducted by the accredited Regional Chemical and Agricultural Stations in agricultural farms across Poland over the period 2010-2012. The sampling sites were divided between Poland's hydrographic regions (Table 1). The vector layer of Poland's division into hydrographic areas (secondorder catchments) used in this study was developed based on the Institute of Meteorology and Water Management (IMGW) hydrological atlas of 1986 "Hydrographic division of Poland - Part II. A map series of the hydrographic division at a scale of 1:200000". The locations of the sites were characterized by geographical coordinates using a GPS tracker, which allowed for sampling to be carried out in the same places in successive years of the study. The location of the sampling sites, divided into soil type and land use, is presented in Fig. 1.

Soil samples were taken in spring and autumn from three soil profile layers, $0-30,30-60$, and $60-90 \mathrm{~cm}$, from fields with a total area of not more than 4 ha. Each total sample (with a weight of about $100 \mathrm{~g}$ ) consisted of 15-20 primary samples collected from an area of not more than $100 \mathrm{~m}^{2}$. In this study only soil samples from the $60-90 \mathrm{~cm}$ layer were subjected to the analysis. Sites where the same land use was continued throughout the entire study period were selected 
Table 1. Number of samples collected from the $60-90 \mathrm{~cm}$ soil layer in grasslands and soils under maize and mixed cereals in the selected hydrographic regions of Poland

\begin{tabular}{lcccc}
\hline Hydrographic region & $\begin{array}{c}\text { Grassland on } \\
\text { mineral soils }\end{array}$ & $\begin{array}{c}\text { Grassland on } \\
\text { organic soils }\end{array}$ & Maize & $\begin{array}{c}\text { Mixed } \\
\text { cereals }\end{array}$ \\
\hline Poland (in total) & 859 & 167 & 826 & 951 \\
Vistula basin & 553 & 95 & 431 & 685 \\
Odra basin & 223 & 36 & 370 & 227 \\
Basin of coastal rivers & 83 & 36 & 25 & 39 \\
\hline
\end{tabular}
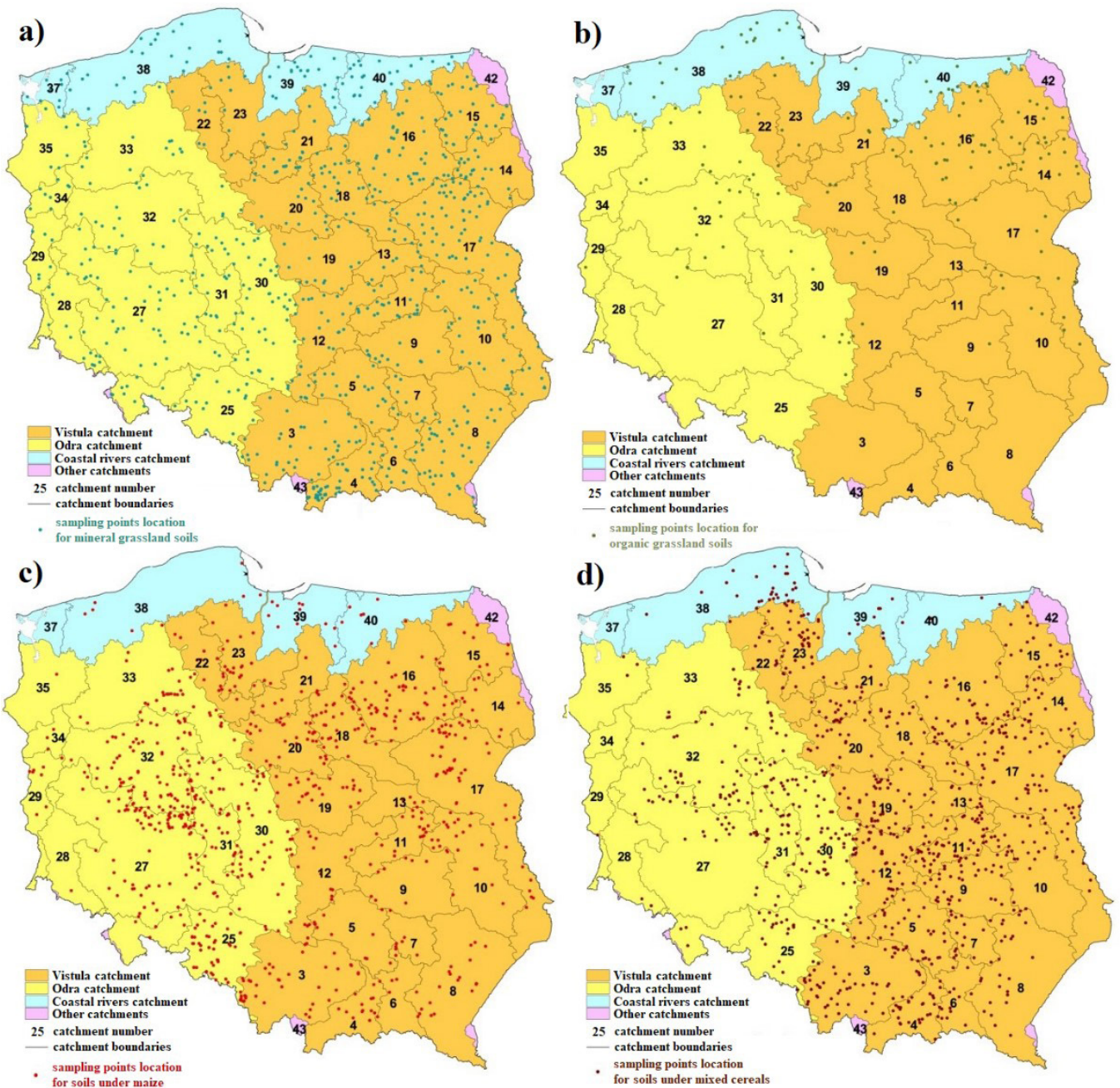

Fig. 1. Location of soil sampling points from a) grasslands on mineral soil, b) grasslands on organic soil, c) maize and d) mixed cereals.

from the grassland area. For comparison, sites where maize and mixed cereals were grown over the period 2010-2012 were also selected (if the same crop was grown during successive years, the average value from the respective years was taken into consideration). The number of soil samples collected for each soil type and land use is listed in Table 2. Additionally, information about the mineral nitrogen fertilization rate for each soil sampling point (land use) was acquired. The fields were classified according to the doses of nitrogen fertilization: 0 (without fertilization), 1-40, 41-80, 81-120 and $>120 \mathrm{~kg} \mathrm{~N} \mathrm{ha}^{-1}$.
The soil samples were subjected to analyses of $\mathrm{N}_{\min }$ in accordance with the PN-R-04028:1997 norm. The collected soil samples were used to determine the mineral nitrogen content in the $60-90 \mathrm{~cm}$ layer which were kept at a temperature of $-18^{\circ} \mathrm{C}$. The soil samples with a natural moisture content (after defrosting) were subjected to extraction with a $1 \%$ potassium sulphate solution at a ratio of $1: 10$. For the extracts obtained, both nitrate and ammonium nitrogen content were determined spectrophotometrically using a Skalar San Plus System auto-analyser. Dry matter content was also determined in the examined samples. Mineral 
Table 2. Number of analysed samples taken from the $60-90 \mathrm{~cm}$ soil layer in grasslands and soils under maize and mixed cereals

\begin{tabular}{llc}
\hline Crop type/land use & Total & $\begin{array}{c}\text { Number of } \\
\text { samples }\end{array}$ \\
\hline \multirow{2}{*}{$\begin{array}{l}\text { Grassland on mineral } \\
\text { soils }\end{array}$} & pastures & 859 \\
& hay and pasture use & 521 \\
& alternate use & 160 \\
& Total & 84 \\
Grassland on organic & meadows & 98 \\
soils & pastures & 167 \\
& hay and pasture use & 111 \\
Maize & alternate use & 17 \\
Mixed cereals & & 026 \\
\hline
\end{tabular}

nitrogen content, in the form of total nitrate and ammonium nitrogen, was expressed in $\mathrm{mg} \mathrm{kg}^{-1}$ of dry weight of the soil sample.

Based on the average mineral nitrogen content calculated for individual sites, its spatial distribution was shown in Poland's hydrographic areas and analysed in relation to specific land uses. Interpolation was performed using ArcView software which applied the IDW (inverse distance weighting) method, which is based on the assumption that the value of the trait being investigated at a given point is dependent on the value of this trait in the closest base points). The data from 12 adjacent base points were included. Interpolation was performed with a strength of 3 and without barriers. The generated $1000 \mathrm{~m}$ mesh grid was cropped using the contour of Poland.

\section{RESULTS AND DISCUSSION}

Many authors have drawn attention to the phenomenon of mineral nitrogen movement in soil profile layers, stressing nitrogen losses (Powlson, 1988; Trehan, 1996; Tremblay et al., 2001; Coyne and Frye, 2005). In the opinion of Soon et al. (2001), almost half of mineral nitrogen located in the 0-30 cm layer may migrate to deeper layers due to leaching. Coyne and Frye (2005) also explain this phenomenon by the beneficial influence of biological processes occurring in the soil. The spatial distribution of mineral nitrogen content in the $60-90 \mathrm{~cm}$ layer in grassland soils presented in Fig. 2 a shows that the highest values were recorded in the north-western area of Poland, both in spring and in autumn, especially in the basin of western coastal rivers belonging to the basin of the Vistula; in the Warta region from the conflux with the Prosna to the mouth of the Noteć; in the Noteć basin, and also in the regions of the main Vistula catchment (the Vistula from the conflux with the Drwęca to the conflux of the Brda and the Vistula from the conflux with the Brda to the estuary leading to the Baltic). The highest contents of $\mathrm{N}_{\min }$ (more than $13 \mathrm{mg}$ $\mathrm{kg}^{-1} \mathrm{DM}$ ) were also found in the north-eastern area, in the regions belonging to the Vistula river basin (the Narew from its sources to the mouth of the Biebrza, the Biebrza basin and the Narew from the conflux with the Biebrza to the mouth of the Bug). High $\mathrm{N}_{\text {min }}$ contents ranging from 7.1 to more than $13 \mathrm{mg} \mathrm{kg}^{-1} \mathrm{DM}$ of this form of nitrogen were found in many regions of the main Odra catchment, with a greater value recorded in spring than in autumn. It results from the fact that in organic soils a mineral nitrogen content was noted to be much higher. This is evident from an analysis of the spatial distribution of mineral nitrogen content in the $60-90 \mathrm{~cm}$ layer in mineral grassland soils presented in Fig. 2b. It shows that the highest content values, which ranged from 7.1 to more than $13 \mathrm{mg} \mathrm{kg}^{-1} \mathrm{DM}$ of $\mathrm{N}$ has been observed in numerous areas belonging to the Odra main catchment, with a higher number of them recorded in autumn rather than in spring. With regard to the area of the other main catchments, i.e. the catchments of the Vistula River and of the rivers of the coastal regions, the abovementioned mineral nitrogen contents were only found in some hydrographic regions, with values of less than $5.0 \mathrm{mg}$ $\mathrm{kg}^{-1} \mathrm{DM}$ being predominant.

When comparing the spatial distribution of mineral nitrogen in grassland soils and soils under maize (Fig. 2c) and mixed cereal crops (Fig. 2d), attention should be paid to a large area, being more than half of the territory studied, where the contents of this nutrient range from 7.0 to more than $13 \mathrm{mg} \mathrm{kg}^{-1} \mathrm{DM}$. This trend was particularly visible in the area under maize crops (Fig. 2c). Similarly, as in the case of grasslands, the highest mineral nitrogen contents were found in hydrographic regions belonging to the Odra basin and in the south-eastern part of Poland, in regions which are part of the Vistula catchment. With regard to soils on which mixed cereals were grown, high mineral nitrogen contents were noted in a slightly smaller area compared to the area under maize, but larger than in the case of grasslands (Fig. 2d). As far as cereal crops are concerned, the highest contents, ranging from 11.1 to more than 13.0 $\mathrm{mg} \mathrm{kg}^{-1} \mathrm{DM}$, occurred in hydrographic regions within the Odra basin (especially in spring) and in regions within the Vistula basin in the south of Poland.

It has already been stated that the mineral nitrogen content $\mathrm{N}$ in the soil layer $60-90 \mathrm{~cm}$ varied significantly depending on the soil type. In all of the assessed catchments higher $\mathrm{N}$ contents were observed for organic soils than for mineral soils (Fig. 3). The average $\mathrm{N}$ content for the entire Polish area was $7.4 \mathrm{mg} \mathrm{kg}^{-1} \mathrm{DM}$ in mineral soils and $34.2 \mathrm{mg} \mathrm{kg}^{-1} \mathrm{DM}$ in organic soils. Significantly higher mineral nitrogen contents in mineral soils than the Polish averages were observed in 10 sub-basins, with the highest value found in catchment no. 26 (the Nysa Kłodzka basin) in the Odra basin - $14.6 \mathrm{mg} \mathrm{kg}^{-1} \mathrm{DM}$, and in the Odra basin in the hydrographic region No. 31 (the Prosna River basin) 
a

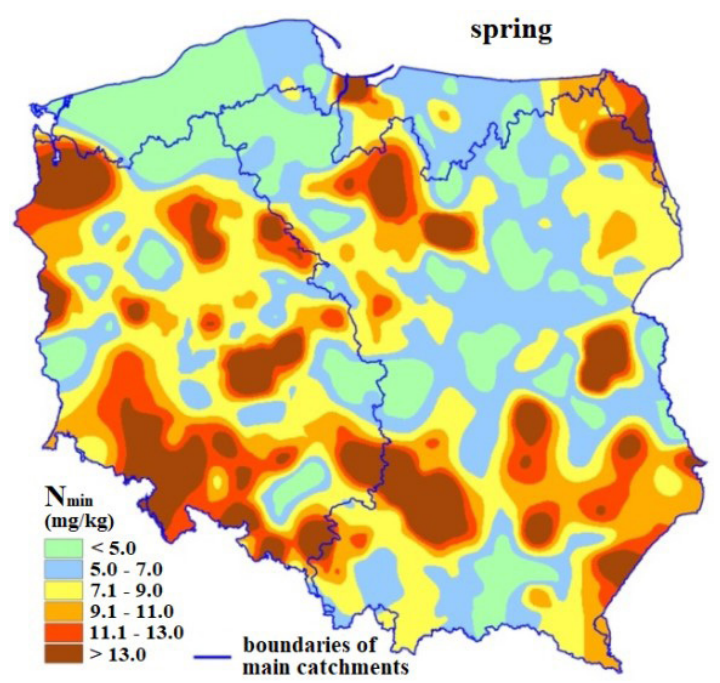

b

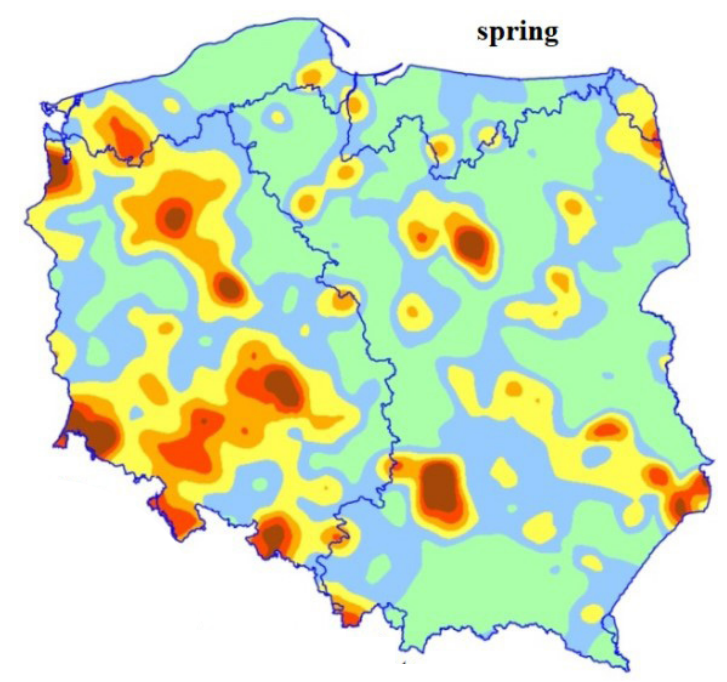

c

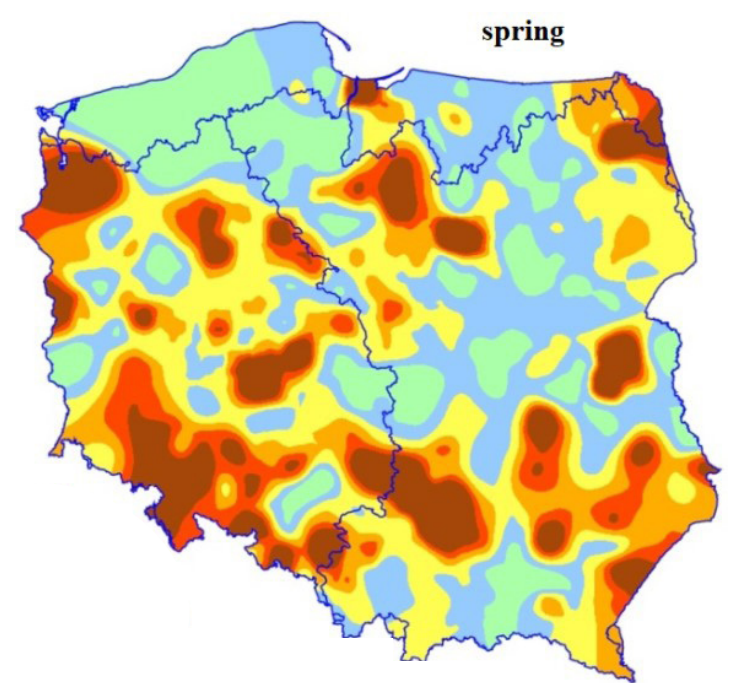

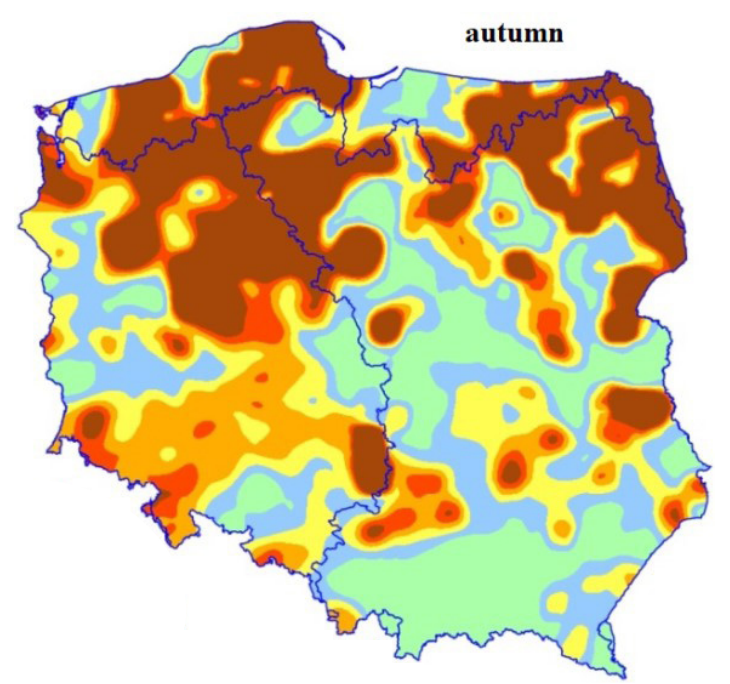
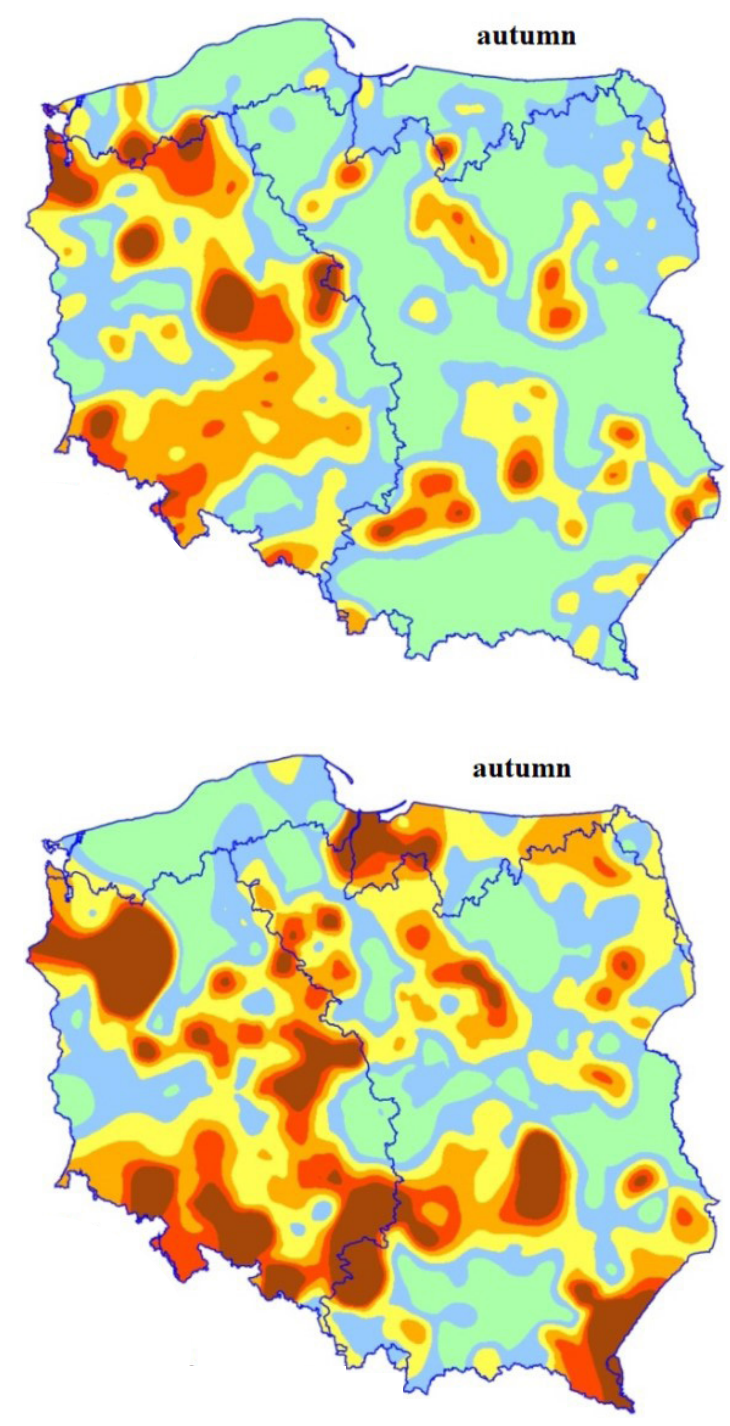

Fig. 2. Spatial distribution of $\mathrm{N}_{\min }$ content in the $60-90 \mathrm{~cm}$ layer of: a - grassland soils (mineral and organic), b - mineral grassland soil, c - mineral soil under maize, $\mathrm{d}$ - mineral soil under mixed cereals; during the spring and autumn period in Poland's selected hydrographic areas. 
d

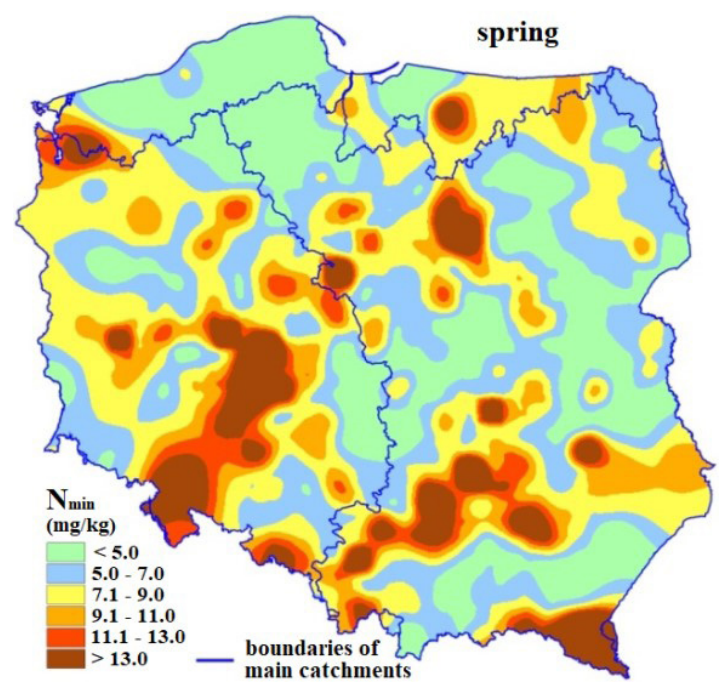

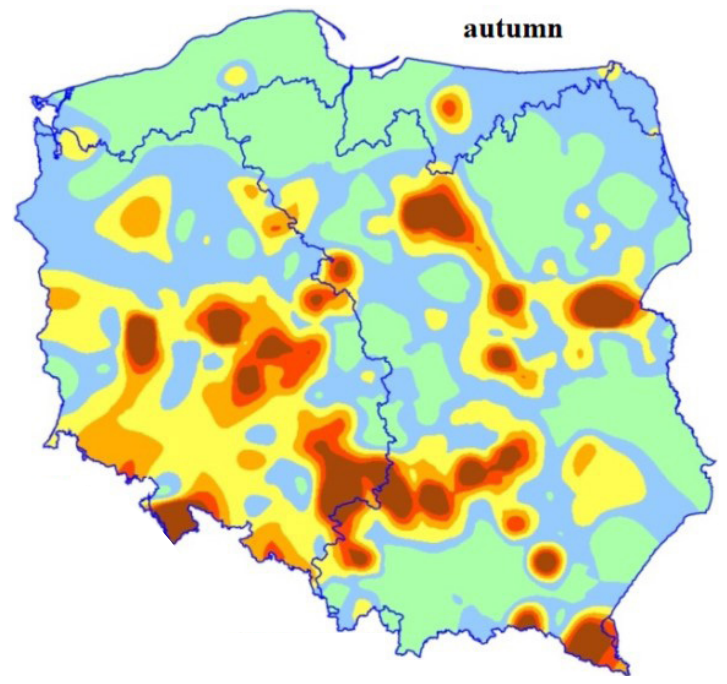

Fig. 2. Continuation.

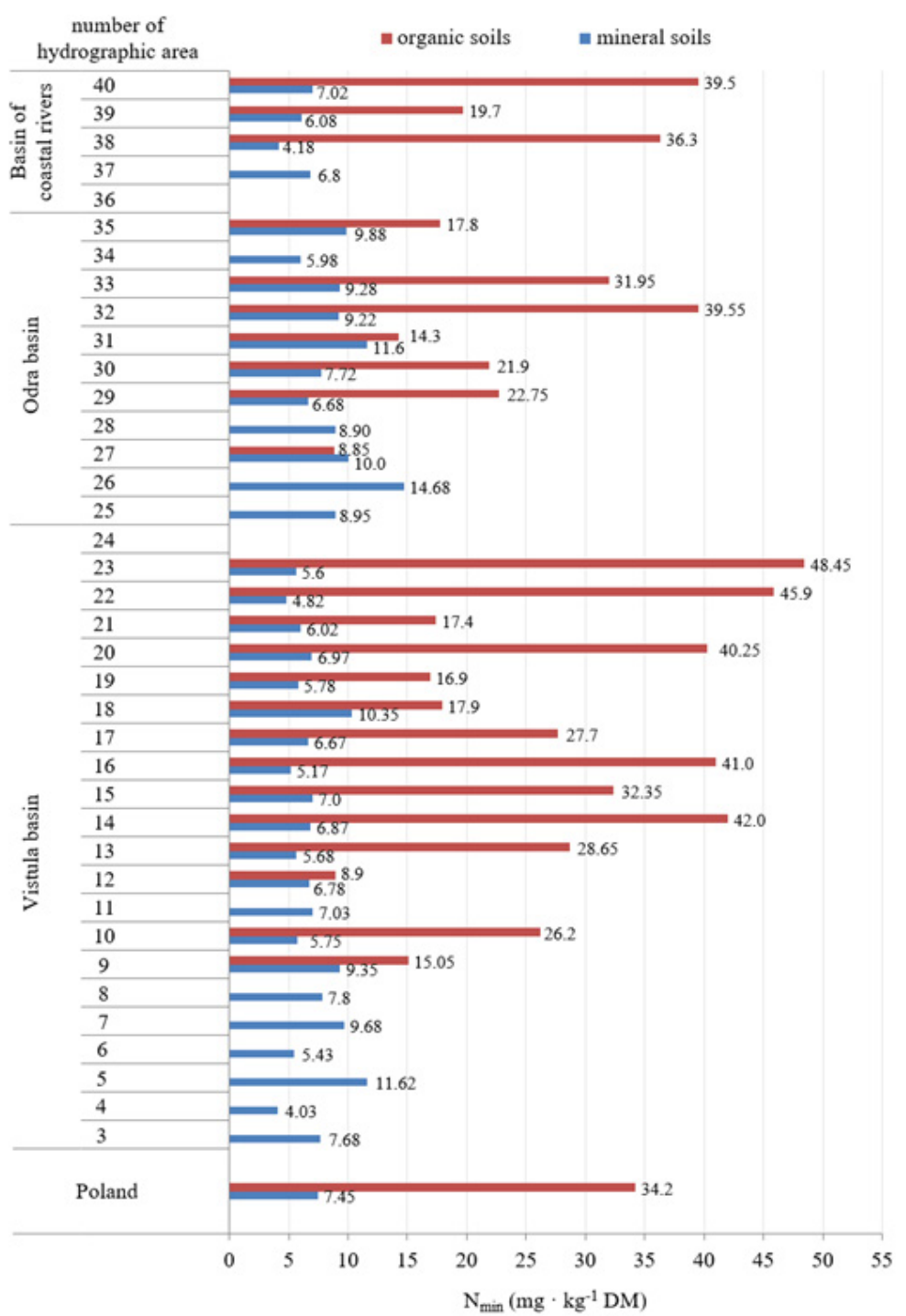

Fig. 3. Average mineral nitrogen content $\mathrm{N}_{\min }$ in the $60-90 \mathrm{~cm}$ soil layer in the selected hydrographic areas of Poland depending on the soil type. 
- $11.6 \mathrm{mg} \mathrm{kg}^{-1} \mathrm{DM}$. As for organic soils, higher contents of $\mathrm{N}_{\min }$ than the Polish average were observed for 7 subcatchments, with the highest value being recorded in region No. 23 (the Vistula from the mouth of the Brda to the estuary leading to the Baltic) and No. 22 (the Vistula from the conflux with the Drwęca to the conflux with the Brda) in the Vistula basin (48.4 and $45.9 \mathrm{mg} \mathrm{kg}^{-1} \mathrm{DM}$, respectively). The lowest content of mineral nitrogen in mineral soils in the 60-90 cm layer was recorded in hydrographic region No. 4 (the Dunajec basin) in the Vistula basin $\left(4.0 \mathrm{mg} \mathrm{kg}^{-1} \mathrm{DM}\right)$ and in region No. 38 (the basin of the western coastal rivers to the conflux with the Vistula River) belonging to the main catchment - the basin of the coastal rivers $\left(4.2 \mathrm{mg} \mathrm{kg}^{-1}\right.$ $\mathrm{DM})$. On the other hand, in organic soils, the lowest content was found in region No. 27 (the Odra from the conflux with the Nysa Kłodzka to the mouth of the Bóbr) in the Odra basin $\left(8.8 \mathrm{mg} \mathrm{kg}^{-1} \mathrm{DM}\right)$ and in region No. 12 (Pilica river basin) in the basin of the Vistula ( $\left.8.9 \mathrm{mg} \mathrm{kg}^{-1} \mathrm{DM}\right)$. Higher amounts of $\mathrm{N}_{\min }$ in organic soils were observed compared to mineral soils, both for the spring and autumn sampling dates. These findings confirmed the studies of Sapek and Sapek (2007) and Pietrzak et al. (2006). Larger values of $\mathrm{N}_{\text {min }}$ content in the $60-90 \mathrm{~cm}$ soil layer in organic soils may be due to weaker mineralization in mineral soils as a result of limited C content. Sapek (2010) stated that the soil's abundance in organic matter may affect the efficiency of nitrogen mineralization. This was confirmed by the recent studies of Tian et al. (2017), who showed that net N mineralization in subsoil is limited by low amounts of a labile $\mathrm{C}$ source (which provides energy) and degradable organic $\mathrm{N}$ (which provides material). Additionally, Hatch et al. (2002) demonstrated that nitrogen immobilization is a result of the increased activity of soil microorganisms.

The mineral nitrogen content in the $60-90 \mathrm{~cm}$ soil layer in Poland's main catchments (Fig. 4) varied on average from $12.6 \mathrm{mg} \mathrm{kg}^{-1} \mathrm{DM}$ in the basin of the coastal rivers during the spring period to $14.4 \mathrm{mg} \mathrm{kg}^{-1} \mathrm{DM}$ in the Odra basin during autumn. The average content of this nutrient in the soil layer, which was beyond the reach of the root system, was respectively 14.3 (in spring) and $14.0 \mathrm{mg} \mathrm{kg}^{-1}$ DM (in autumn) for the entire area of Poland. In spring, higher values were only found in the Vistula basin, whereas during the autumn months such values were found in the Odra basin and in the basin of the coastal rivers (Fig. 4). Compared to the averages for the entire area of Poland in spring, significantly lower $\mathrm{N}_{\min }$ contents were found in soil samples collected from the basin of the coastal rivers, while in autumn - those from the Vistula basin were lower.

When comparing the average mineral nitrogen content in the $60-90 \mathrm{~cm}$ layer in grassland soils and soils under selected agricultural fodder crops, the lowest values were found in grassland soils in the area of almost all the main river catchments studied, regardless of the sampling date (Fig. 5). An exception to this trend were the catchments within the basin of the coastal rivers where lower $\mathrm{N}_{\min }$ con-

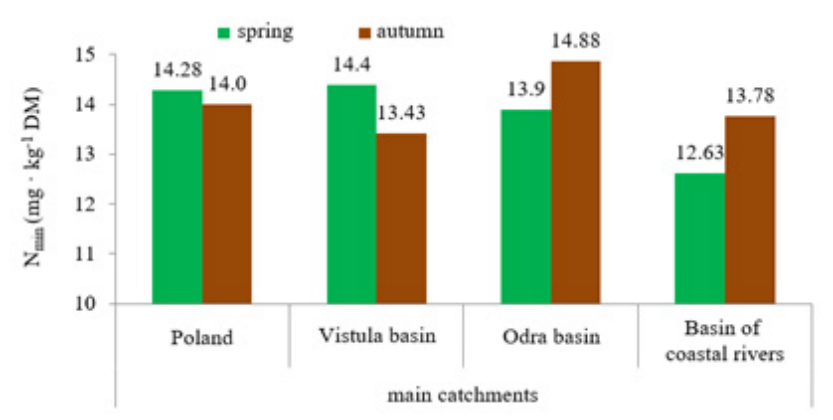

Fig. 4. Average mineral nitrogen content $\mathrm{N}_{\min }$ in the $60-90 \mathrm{~cm}$ soil layer in the spring and autumn period in the main selected hydrographic regions of Poland.

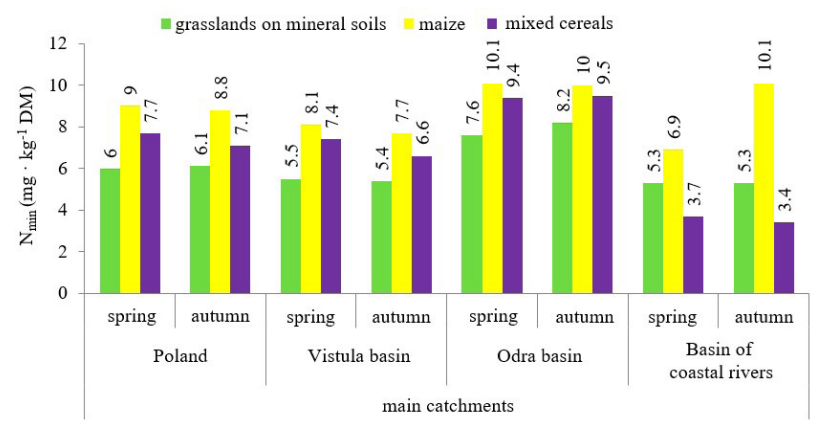

Fig. 5. Average mineral nitrogen content $\mathrm{N}_{\min }$ in the $60-90 \mathrm{~cm}$ soil layer in the main selected hydrographic regions of Poland depending on agricultural land use and sampling date.

tents were recorded in soil material collected from soils under mixed cereals as compared to grassland soils. In all of the locations studied, the highest contents of this nutrient were found in soils under maize. Regardless of agricultural land use and the sampling date, the highest mineral nitrogen contents were determined for soils in the Odra basin, whereas the lowest ones were found in the basin of the coastal rivers, except for soils under maize sampled in the autumn period when one of the highest contents of the studied nutrient was noted $\left(10.1 \mathrm{mg} \mathrm{kg}^{-1} \mathrm{DM}\right)$. GarcíaDíaz et al. (2017) noted for vineyards that vegetation cover had a significant impact on runoff and dissolved mineral nitrogen losses, and as a result, a differentiation of the $\mathrm{N}_{\text {min }}$ content in the deeper soil layers. Also, De Notaris et al. (2017) showed that vegetation cover influences $\mathrm{N}$ leaching, with spring wheat and potatoes having the highest rate of nitrogen leaching.

When evaluating the mineral nitrogen content in the $60-90 \mathrm{~cm}$ layer of mineral grassland soils, depending on land use and the sampling date, the highest values were found in meadows in each of the main catchments evaluated, while the lowest ones were found in hay and pasture grasslands, as well as in alternating grasslands (Fig. 6). With the exception of grasslands used variably (hay and pasture use), for which these values reached their lowest level, in the case of the other grassland use types, the highest contents of the mineral form of nitrogen were found in 


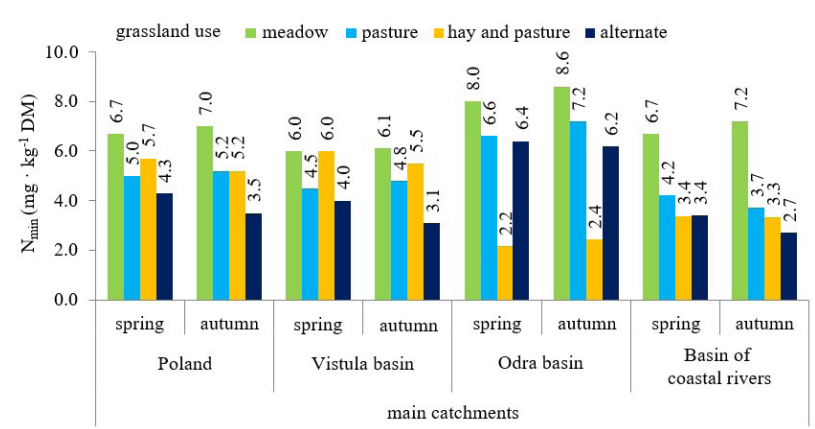

Fig. 6. Average mineral nitrogen content $\mathrm{N}_{\text {min }}$ in the $60-90 \mathrm{~cm}$ soil layer in the main selected hydrographic regions of Poland depending on grassland use and sampling date.

the Odra basin. Taking into account the average values for the main catchments, the largest differences in the content of the evaluated nutrients in spring and autumn were noted in alternating grasslands (in arable land), with the highest values found in the Vistula basin. Bałuch-Małecka et al. (2004) showed that the most effective organic mass mineralization process was ensured by grass mixtures with a significant share of meadow clover and alfalfa.

In order to determine the factors that have the greatest influence over the spatial soil $\mathrm{N}_{\min }$ distribution in Poland, the determination coefficients $\left(\mathrm{R}^{2}\right)$ were calculated (Table 3). They reflect the relationship between mineral nitrogen content $\mathrm{N}_{\min }$ in the $60-90 \mathrm{~cm}$ soil layer under grasslands, maize, mixed cereals and the levels of $\mathrm{N}$ fertilization, soil $\mathrm{pH}$ and livestock density. Determination coefficients were calculated for both spring and autumn sampling dates, in addition to those values calculated on an annual basis. It transpired that livestock density mainly affected mineral nitrogen content $\mathrm{N}_{\min }$ in the $60-90 \mathrm{~cm}$ soil layer in grassland soils, regardless of the carbon content (mineral or organic soils) or the sampling date (spring or autumn), with $\mathrm{R}^{2}$ even reaching 0.99 for grassland mineral soils for the spring sampling date. As was shown by Baryła and Kulik (2006) the livestock density may significantly influence the nitrogen supply to the soil. $\mathrm{N}_{\min }$ content in grassland mineral soils was also strongly influenced by the $\mathrm{pH}$ of the soil, in contrast to grassland organic soils. In soils under maize crops the greatest influence over the spatial distribution of $\mathrm{N}_{\min }$ content in the $60-90 \mathrm{~cm}$ soil layer had $\mathrm{pH}$ value of the soil, whereas the dose of $\mathrm{N}$ fertilization did not have a significant effect over this distribution. It may be hypothesized with some justification that maize is able to assimilate more $\mathrm{N}$ from fertilizers, thus preventing it from migrating into the deeper soil profile layers. On the contrary, for soils under mixed cereals, not only soil $\mathrm{pH}$ has a strong influence over the distribution of $\mathrm{N}_{\min }$ content in the $60-90 \mathrm{~cm}$ soil layer, but also the dose of $\mathrm{N}$ fertilization greatly influences this distribution. Grover et al. (2017) observed that increases in $\mathrm{pH}$ values lead to changes in the availability of resources for microbes, thus altering their community structure, with the final result of modifying their activity and $\mathrm{C}$-use efficiency. The relative abundance and diversity of bacteria were positively related to $\mathrm{pH}$ (Rousk et al., 2010). This effect has an influence over the mineralization process, leading to positive correlations between the mineral nitrogen content $\mathrm{N}_{\min }$ in the $60-90 \mathrm{~cm}$ soil layer and soil $\mathrm{pH}$. Similar correlations were also found in the studies of Sapek and Kalińska (2004, 2007) and Sapek (2010). In their opinion, lower acidity levels reduce the rate of release of the ammonium form of nitrogen and at the same time promotes the nitrification and the release of the nitrate form of nitrogen.

\section{CONCLUSIONS}

1. Soil mineral nitrogen content, particularly in the $60-90 \mathrm{~cm}$ layer, is a serious threat to water quality (especially outside the growing season). During the assessment (both in the spring and autumn dates of sampling) of mineral nitrogen content in the $60-90 \mathrm{~cm}$ layer of grassland soils relative to other selected agricultural crops in Poland's hydrographic regions, it was confirmed that there are observable differences in the content of this form of nitrogen depending on the type of soil and land use.

2 . The $\mathrm{N}_{\min }$ content in the $60-90 \mathrm{~cm}$ soil layer in specific hydrographic regions was particularly diversified depending on the content of organic carbon in the soil samples and varied according to land use.

Table 3. Determination coefficients $\left(R^{2}\right)$ between mineral nitrogen content $N_{\min }$ in the $60-90 \mathrm{~cm}$ soil layer in grasslands and soils under maize and mixed cereals during spring and autumn sampling dates and the dose of $\mathrm{N}$ fertilization, soil pH and livestock density

\begin{tabular}{lcccccc}
\hline \multirow{2}{*}{ Land use } & \multicolumn{2}{c}{ Dose of N fertilization } & \multicolumn{2}{c}{ Soil pH } & \multicolumn{2}{c}{ Livestock density } \\
\cline { 2 - 7 } & spring & autumn & spring & autumn & spring & autumn \\
\hline Grasslands on mineral soils & 0.45 & 0.69 & 0.94 & 0.85 & 0.99 & 0.94 \\
Grasslands on organic soils & 0.23 & 0.07 & 0.23 & 0.23 & 0.48 & 0.90 \\
Maize & 0.28 & 0.01 & 0.96 & 0.83 & 0.01 & 0.74 \\
Mixed cereals & 0.69 & 0.85 & 0.92 & 0.96 & 0.62 & 0.20 \\
Total mineral soils & 0.69 & 0.81 & 0.98 & 0.92 & 0.86 & 0.14 \\
Soils in total & 0.19 & 0.20 & 0.59 & 0.81 & 0.74 \\
Soils in total - annualized & \multicolumn{2}{c}{0.01} & & 0.72 & & 0.05 \\
Mineral soils in total - annualized & \multicolumn{2}{c}{0.76} & & 0.98 & & 0.96 \\
Organic soils in total - annualized & \multicolumn{2}{c}{0.05} & & 0.03 & & 0.01 \\
\hline
\end{tabular}


3. For grasslands, the highest contents of nitrogen were found in the north-western area, while slightly lower $\mathrm{N}$ contents were observed in several regions of the main Odra catchment and west of the Vistula River.

4. In soils under maize crops, the mineral nitrogen content was significantly higher than it was in the case of grasslands and primarily included the hydrographic regions of the basin of the Odra River, in particular in its southwestern stretch, and the Vistula River on its western and south-eastern side. Substantially high levels of mineral nitrogen content were also found in the north-eastern area of Poland.

5. Areas of soil from arable land under mixed cereals, with the highest $\mathrm{N}_{\min }$ content in the layer beyond the reach of the main mass of roots were predominantly located in hydrographic regions belonging to the main Odra catchment and to the catchment of the Vistula River in its upper course. This content was higher than the values found in grassland soils but lower than those in soils under maize.

6. Among the factors with the greatest influence over the spatial soil $\mathrm{N}_{\min }$ distribution in Poland is soil $\mathrm{pH}$. In grassland soils, regardless of the carbon content, livestock density has a significant effect over the $\mathrm{N}_{\min }$ content in the $60-90 \mathrm{~cm}$ soil layer, whereas for soils under mixed cereals the dose of $\mathrm{N}$ fertilization has a strong influence on $\mathrm{N}_{\text {min }}$ content

7. The results obtained have both an environmental and practical significance. They may help to identify regions (catchments) where agriculture has a more substantial impact (potential groundwater pollution) on the natural environment and facilitate the search for solutions leading to the sustainable management of nitrogen fertilization taking into account the diversity of Polish soils, organic carbon content and land use.

Conflict of interest: The Authors do not declare any conflict of interest.

\section{REFERENCES}

Antonkiewicz J., Kolodziej B., Bielińska E.J., and GleńKarolczyk K., 2018. The use of macroelements from municipal sewage sludge by the Multiflora rose and the Virginia fanpetals. J. Ecol. Eng., 19(6), 1-13. https://doi. org/10.12911/22998993/92889

Bałuch-Małecka A., Benedycki S., and Benedycka Z., 2004. Post-harvest value of legume-grass mixtures (in Polish). Annales UMCS sec. E, Agricultura, 59(1), 449-455.

Baranowski P., Krzyszczak J., Sławiński C., Hoffmann H., Kozyra J., Nieróbca A., Siwek K., and Gluza A., 2015. Multifractal analysis of meteorological time series to assess climate impacts. Climate Research, 65, 39-52. https://doi. org/10.3354/cr01321

Baryla R. and Kulik M., 2006. Content of nitrogen and basic mineral components in pasture sward in different years of its utilization (in Polish). Annales UMCS sec. E, Agricultura, $61,157-164$
Convention, 1992. The convention on the protection of the marine environment of the Baltic Sea Area, Dz. U. (J. Laws) of 2000, No. 28, item 346, the so-called Helsinki Convention.

Coyne M.S. and Frye W.W., 2005. Nitrogen in soil. Cycle. Encyclopedia of Soil in the Environment. Hillel D., Elsevier Ltd., 13-21.

De Notaris C., Rasmussen J., Sørensen P., and Olesen J.E., 2017. Nitrogen leaching: a crop rotation perspective on the effect of $\mathrm{N}$ surplus, field management and use of catch crops. Agric., Ecosys. Environ., 255, 1-11. https://doi.org/10.1016/j.agee.2017.12.009

Directive, 91/676/CEE. The Council Directive of 12 December 1991 concerning the protection of waters against pollution caused by nitrates from agricultural sources (91/676/EEC, OJ L375/1), the so-called Nitrate Directive.

Directive, 2000/60/EC. The Directive of the European Parliament and of the Council of 23 October 2000 establishing a framework for Community action in the field of water policy (2000/60/EC OJ L375/10), the so-called Water Framework Directive.

Fotyma M., Kęsik K., and Pietruch Cz., 2010. Mineral nitrogen in soils of Poland as an indicator of plants nutrient requirements and soil water cleanness (in Polish). Nawozy i Nawożenie, 38, 4-83.

Fronzek S., Pirttioja N., Carter T.R., Bindi M., Hoffmann H., Palosuo T., Ruiz-Ramos M., Tao F., Trnka M., Acutis M., Asseng S., Baranowski P., Basso B., Bodin P., Buis S., Cammarano D., Deligios P., Destain M.-F., Dumont B., Ewert F., Ferrise R., François L., Gaiser T., Hlavinka P., Jacquemin I., Kersebaum K.C., Kollas C., Krzyszezak J., Lorite I.J., Minet J., Minguez M.I., Montesino M., Moriondo M., Müller C., Nendel C., Öztürk I., Perego A., Rodríguez A., Ruane A.C., Ruget F., Sanna M., Semenov M.A., Sławiński C., Stratonovitch P., Supit I., Waha K., Wang E., Wu L., Zhao Z., and Rötter R.P., 2018. Classifying multi-model wheat yield impact response surfaces showing sensitivity to temperature and precipitation change. Agricultural Systems, 159, 209-224. https://doi.org/10.1016/j.agsy.2017.08.004

García-Díaz A., Bienes R., Sastre B., Novara A., Gristina L., and Cerdà A., 2017. Nitrogen losses in vineyards under different types of soil groundcover. A field runoff simulator approach in central Spain. Agric., Ecosys. Environ., 236, 256-267. https://doi.org/10.1016/j.agee.2016.12.013

Grover S.P., Butterly C.R., Wang X., and Tang C., 2017. The short-term effects of liming on organic carbon mineralisation in two acidic soils as affected by different rates and application depths of lime. Biol. Fertil. Soils, 53, 431-443.

GUS, 2018. Statistical Yearbook of Agriculture. www.stat.gov.pl

Hatch D., Goulding K., and Murphy D., 2002. Nitrogen. Agriculture, hydrology and water quality. CABI Publishing, 7-27.

Hoffmann H., Baranowski P., Krzyszczak J., Zubik M., Sławiński C., Gaiser T., and Ewert F., 2017. Temporal properties of spatially aggregated meteorological time series. Agricultural and Forest Meteorology, 234-235, 247257. https://doi.org/10.1016/j.agrformet.2016.12.012

Krzyszczak J., Baranowski P., Hoffmann H., Zubik M., and Slawiński C., 2017a. Analysis of Climate Dynamics Across a European Transect Using a Multifractal Method. In: Advances in Time Series Analysis and Forecasting: Selected 
Contributions from ITISE 2016. (Eds I. Rojas, H. Pomares, O. Valenzuela), Contributions to Statistics. Springer Int. Publishing, Cham, 103-116. https://doi.org/10.1007/ 978-3-319-55789-2_8

Krzyszczak J., Baranowski P., Zubik M., and Hoffmann H., 2017b. Temporal scale influence on multifractal properties of agro-meteorological time series. Agric. Forest Meteorol., 239, 223-235. https://doi.org/10.1016/j.agrformet.2017.03.015

Krzyszczak J., Baranowski P., Zubik M., Kazandjiev V., Georgieva V., Slawiński C., Siwek K., Kozyra J., and Nieróbca A., 2019. Multifractal characterization and comparison of meteorological time series from two climatic zones. Theoretical Appl. Climatology, 137, 1811-1824. https://doi.org/10.1007/s00704-018-2705-0

Lamorski K., Pastuszka T., Krzyszczak J., Slawiński C., and Witkowska-Walczak B., 2013. Soil water dynamic modeling using the physical and support vector machine methods. Vadose Zone J., 12(4). https://doi.org/10.2136/vzj2013.05.0085

Lipiński W., 2010. The content of mineral nitrogen in arable soils of nitrate vulnerable zones (NVZ) (in Polish). Nawozy i Nawożenie, 38, 111-120.

Marecik R., Biegańska-Marecik R., Cyplik P., Lawniczak L., and Chrzanowski $\mathbf{L}$., 2013. Phytoremediation of industrial wastewater containing nitrates, nitroglycerin, and nitroglycol. Polish J. Environ. Stud., 22(3), 773-780.

Murat M., Malinowska I., Gos M., and Krzyszczak J., 2018. Forecasting daily meteorological time series using ARIMA and regression models. Int. Agrophys., 32(2), 253-264. https://doi.org/10.1515/intag-2017-0007

Powlson D.S., 1988. Measuring and minimising losses of fertilizer nitrogen in arable agriculture. In: Nitrogen Efficiency in Agricultural Soils, Elsevier Applied Science, 231-245.

Pietrzak S., Urbaniak M., and Sapek B., 2006. The assessment of changes of the concentration and leaching of mineral forms of nitrogen in soil solutions (in Polish). WodaŚrodowisko-Obszary Wiejskie, 6(17), 51-63.

Pirttioja N., Carter T.R., Fronzek S., Bindi M., Hoffmann H., Palosuo T., Ruiz-Ramos M., Tao F., Trnka M., Acutis M., Asseng S., Baranowski P., Basso B., Bodin P., Buis S., Cammarano D., Deligios P., Destain M.-F., Dumont B., Ewert F., Ferrise R., François L., Gaiser T., Hlavinka P., Jacquemin I., Kersebaum K.C., Kollas C., Krzyszczak J., Lorite I.J., Minet J., Minguez M.I., Montesino M., Moriondo M., Müller C., Nendel C., Öztürk I., Perego A., Rodríguez A., Ruane A.C., Ruget F., Sanna M., Semenov M.A., Sławiński C., Stratonovitch P., Supit I., Waha K., Wang E., Wu L., Zhao Z., and Rötter R.P., 2015. Temperature and precipitation effects on wheat yield across a European transect: a crop model ensemble analysis using impact response surfaces. Climate Res., 65, 87-105. https://doi.org/10.3354/cr01322

PN-R-04028:1997 Agrochemical soil analysis - Determination of nitrate and ammonium ions in the mineral soils.

Randal G.W. and Goss M.J., 2008. Nitrate losses to surface water through subsurface tile drainage. In: Nitrogen in the Environment: Sources, Problems, and Management (Eds J.L. Hatfield, R.F. Follett). Elsevier, 145-175.

Regulation, 2002. Regulation of the Minister of Environment of 23 December 2002 concerning specific requirements to be met by action programs aimed at reducing runoff of nitrogen from agricultural sources, Dz.U. (J. Laws) of 2003, No. 4 , item 44 .

Rodríguez A., Ruiz-Ramos M., Palosuo T., Carter T.R., Fronzek S., Lorite I.J., Ferrise R., Pirttioja N., Bindi M., Baranowski P., Buis S., Cammarano D., Chen Y., Dumont B., Ewert F., Gaiser T., Hlavinka P., Hoffmann H., Höhn J.G., Jurecka F., Kersebaum K.C., Krzyszczak J., Lana M., Mechiche-Alami A., Minet J., Montesino M., Nendel C., Porter J.R., Ruget F., Semenov M.A., Steinmetz Z., Stratonovitch P., Supit I., Tao F., Trnka M., de Wit A., and Rötter R.P., 2018. Implications of crop model ensemble size and composition for estimates of adaptation effects and agreement of recommendations. Agric. Forest Meteorol., 264, 351-362.

https://doi.org/10.1016/j.agrformet.2018.09.018

Rousk J., Bååth E., Brookes P.C., Lauber C.L., Lozupone C., Caporaso J.G., Knight R., and Fierer N., 2010. Soil bacterial and fungal communities across a $\mathrm{pH}$ gradient in an arable soil. ISME J., 4, 1340-1351.

http://dx.doi.org/10.1038/ismej.2010.58

Ruiz-Ramos M., Ferrise R., Rodríguez A., Lorite I.J., Bindi M., Carter T.R., Fronzek S., Palosuo T., Pirttioja N., Baranowski P., Buis S., Cammarano D., Chen Y., Dumont B., Ewert F., Gaiser T., Hlavinka P., Hoffmann H., Höhn J.G., Jurecka F., Kersebaum K.C., Krzyszczak J., Lana M., Mechiche-Alami A., Minet J., Montesino M., Nendel C., Porter J.R., Ruget F., Semenov M.A., Steinmetz Z., Stratonovitch P., Supit I., Tao F., Trnka M., de Wit A., and Rötter R.P., 2018. Adaptation response surfaces for managing wheat under perturbed climate and $\mathrm{CO}_{2}$ in a Mediterranean environment. Agricultural Systems, 159, 260-274. https://doi.org/10.1016/j.agsy.2017.01.009

Sapek B., 2010. Nitrogen and phosphorus release from soil organic matter (in Polish). Woda-Środowisko-Obszary Wiejskie 10, 3(31), 229-256.

Sapek B. and Kalińska D., 2004. Mineralization of soil organic nitrogen compounds in the light of long-term grassland experiments in IMUZ (in Polish). Woda-ŚrodowiskoObszary Wiejskie, 4, 1(10), 183-200.

Sapek B. and Kalińska D., 2007. Mineralization of nitrogen and phosphorus compounds in the soil of agriculturally used and not used meadow (in Polish). Roczn. Glebozn., 58(1), 109-120.

Sapek A. and Sapek B., 2007. Changes of the mineral nitrogen content in meadow soil on the background of differentiated nitrogen fertilization. Roczn. Glebozn., 58(1), 99-108.

Soon Y.K., Clayton G.W., and Rice W.A., 2001. Tillage and previous crop effects on dynamics of nitrogen in a wheat - soil system. Agronomy J., 93, 842-849.

Tian Q., Wang X., Wang D., Wang M., Liao C., Yang X., and Liu F., 2017. Decoupled linkage between soil carbon and nitrogen mineralization among soil depths in a subtropical mixed forest. Soil Biol. Biochem., 109, 135-144.

https://doi.org/10.1016/j.soilbio.2017.02.009

Tkaczyk P., Bednarek W., Dresler S., Krzyszczak J., Baranowski P., and Slawiński C., 2017. Relationship between assimilable-nutrient content and physicochemical properties of topsoil. Int. Agrophys., 31(4), 551-562. https://doi.org/10.1515/intag-2016-0074 
Tkaczyk P., Bednarek W., Dresler S., and Krzyszczak J., $2018 a$. The effect of some soil physicochemical properties and nitrogen fertilisation on winter wheat yield. Acta Agrophysica, 25(1), 107-116. https://doi.org/10.31545/aagr0009

Tkaczyk P., Bednarek W., Dresler S., Krzyszczak J., Baranowski P., and Brodowska M.S., 2018b. Content of certain macro and microelements in orchard soils in relation to agronomic categories and reaction of these soils. J. Elementology, 23(4), 1361-1372. https://doi.org/10.5601/ jelem.2018.23.1.1639

Trehan S.P., 1996. Immobilisation of ${ }^{15} \mathrm{NH}^{4+}$ in three soils by chemical and biological processes. Soil Biol. Biochem., 28(8), 1021-1027.

Tremblay N., Scharpf H.Ch., Weier U., Laurence H., and Owen J., 2001. Nitrogen management in field vegetables. A guide to efficient fertilisation. Agric. Agri-Food Canada, $1-63$.

Walczak R.T., Witkowska-Walczak B., and Baranowski P., 1997. Soil structure parameters in models of crop growth and yield prediction. Physical submodels. Int. Agrophysics, 11, 111-127.
Walkiewicz A., Brzezińska M., and Bieganowski A., 2018. Methanotrophs are favored under hypoxia in ammoniumfertilized soils. Biol. Fertil. Soils, 1-10. https://doi.org/10.1007/s00374-018-1302-9

Wasilewski Z., 2009. Present status and directions of grassland management according to the requirements of the Common Agricultural Policy (in Polish). Woda-Środowisko-Obszary Wiejskie, 9, 2(26), 169-184.

Wasilewski Z., 2010. Botanical composition and utility value of grazed sward in various habitats. Woda-Środowisko-Obszary Wiejskie, 10, 4, 265-280.

Watros A., Lipińska H., Lipiński W., Tkaczyk P., Krzyszczak J., and Baranowski P., 2018. The impact of fertilization on the mineral nitrogen content in grassland and fodder crop soils (in Polish). Przemysł Chemiczny, 97(11), 1899-1905. https://doi.org/10.15199/62.2018.11.17

Wnuk E., Walkiewicz A., and Bieganowski A., 2017. Methane oxidation in lead-contaminated mineral soils under different moisture levels. Environ. Sci. Poll. Res., 24(8-9), 1-9. https://doi.org/10.1007/s11356-017-0195-8 